\title{
A Második Osztrák Köztársaság az átmeneti idôszakban
}

\author{
The Second Austrian Republic \\ in the Transitional Period
}

Összefoglalás

A 2. világháború után az osztrák államiság és függetlenség helyreállítása egy tízéves idôszakot (1945-1955) ölelt fel. A szövetségesek közötti végsố megegyezést hátráltatta a hidegháború „kirobbanása”, mely több évvel késleltette az osztrák kérdés megoldását. Ausztria sikerének kulcsa egyrészt a belpolitikai, ideértve az alkotmányozási folyamatokat is, másrészt a külpolitikai tényezókben keresendô. Az egymást követô osztrák kormányzatok határozott külpolitikai fellépései és nyugati orientációja nagyban hozzájárult az ország integritásának megórzéséhez. Az osztrák külpolitika sikeresen helyt tudott állni a nemzetközi viszonyok alakulása során, és az is Ausztriának kedvezett, hogy az országot a közép-kelet-európai államokkal ellentétben a szövetségesek együttesen szabadították fel. Az egykori alkotmányos jogrendet visszaállítva, és a múlt alkotmányjogi vívmányaira építve, valamint az elismert jogtudósok, alkotmányjogászok politikai-alkotmányjogi kérdésekbe történő bevonásának köszönhetôen létrejött a demokratikus alapokon múködô és föderális szerkezetú Második Osztrák Köztársaság.

Kulcsszavak: Második Osztrák Köztársaság, alkotmánytörvény, átmeneti idôszak, szövetséges hatalmak, egyezmény, államiság

MARóti DÁvid doktorandusz hallgató, Nemzeti Közszolgálati Egyetem, Közigazgatás-tudományi Doktori Iskola (maroti.david90@gmail.com). 


\section{Summary}

After World War II the Austrian state and independence was restored in a decade (1945-1955). Final agreement between the Allies was hindered by the start of the Cold War, which also delayed finding a solution for the Austrian issue for years. The Austrian success is due in part to the management of home affairs, including constitutional procedures, and partly to foreign policy. The successive Austrian governments' resolute foreign policy actions and consistent Western orientation contributed to the preservation of the country's integrity. The Austrian foreign policy was successful in the international arena, and Austria also benefited from the fact that it was jointly liberated by Allies, unlike the rest of Central and Eastern Europe. After the previous constitutional law and order had been restored, renowned legal, and more specificalyly, constitutional experts were involved in political and constitutional issues to establish the Second Austrian Republic on democratic grounds and in a federal structure, building on historical constitutional achievements.

Keywords: the Second Austrian Republic, constitutional law, the Allies, convention, statehood

\section{A MOSZKVAI NYILATKOZAT}

Ausztriának a 2. világháború alatt nem volt olyan emigráns kormánya, amely képviselhette volna az osztrák érdekeket az ország államiságának helyreállításáért. Az osztrák függetlenség kérdése kezdetben közel sem volt egyértelmú, hiszen akadtak olyan vélemények is, miszerint a német-osztrák szövetséget a nemzetiszocializmus felett aratott győzelem után is fenn kellene tartani. A szövetségesek eleinte csak a területi felosztás kérdését tárgyalták, és az alábbi javaslatokat dolgozták ki (Brauneder, 2003:255):

- Ausztria egy dunai konföderáció tagja legyen a jövóben (Churchill 1942-es javaslata alapján),

- Ausztria egy délnémet föderáció tagja legyen, mely rendelkezik egy, az Adriaitengerhez való kijárattal (Hull amerikai külügyminiszter 1943-as javaslata).

Ausztria államiságát tehát kezdetben egy államközi rendszerben képzelték el, kizárva a Német Birodalomhoz való tartozás lehetôségét. Ezek a tervek azonban fokozatosan elhaltak az amerikai és a szovjet fél támogatásának hiányában. A végleges döntés az 1943. októberi moszkvai értekezleten ${ }^{1}$ született meg. Az Egyesült Államok, az Egyesült Királyság és a Szovjetunió kormánya Ausztria függetlenségének helyreállítására az 1943. október 30-án elfogadott és november 1-jén nyilvánosságra hozott Moszkvai Nyilatkozatban szándékukat fejezték ki. A Nyilatkozatban a részes államok külügyminiszterei elismerték, hogy Ausztria a hitleri expanzió elsô áldozatának tekinthetô, és az 1938. március 12-i Anschlusst semmisnek nyilvánították. Kimondták, hogy Ausztria szabadságát, függetlenségét és államiságát a háború után helyre kell állítani, de ugyan- 
akkor emlékeztettek arra is, hogy Ausztriát a Német Birodalom oldalán történó háborús részvétel miatt felelôsség terheli, ${ }^{2}$ és figyelembe fogják venni, hogy mennyiben járult hozzá önmaga felszabadításához. ${ }^{3}$

\section{A SZÖVETSÉGES HATALMAK ELLENŐRZÉSE}

Ausztria különleges helyzetben volt a háborút viselt országok között, ugyanis nem volt háborút vezetô hatalom, mint a Német Birodalom vagy Olaszország, ugyanakkor olyan felszabadított államnak sem volt tekinthető, mint Lengyelország vagy Belgium.

\section{Az Elsố Ellenôrzési Megállapodás (Erstes Kontrollabkommen) $)^{4}$ és a Szövetséges Tanács Memoranduma}

1945. július 4-én az Egyesült Államok, Nagy-Britannia, a Szovjetunió és Franciaország kormánya Londonban aláírta az Elsố Ellenôrzési Megállapodást (Ausztria nem volt a szerződő felek között). A megállapodás keretében egy ellenőrzési rendszert állítottak fel, melyet az elsố szabadon választott és mind a négy megszálló hatalom által elismert kormány megalakulásáig kívántak fenntartani (Brauneder, 2003:264). A szövetséges ellenórzési apparátus, a Szövetséges Bizottság (Alliierte Kommission für Österreich) a négy főparancsnok (Oberbefehlshaber) alkotta Szövetséges Tanácsból, a főparancsnokok helyetteseiból álló Végrehajtó Bizottságból és a megszálló hatalmak szakértóiból álló csoportokból tevődött össze. A Szövetséges Tanács kizárólag egyhangúlag hozhatott döntéseket. Ezek a szervek csak az osztrák központi állami szervek felett rendelkeztek utasítási jogkörrel, és csak az egész Ausztriát érintố kérdésekben gyakorolhatták hatáskörüket. Az egyes zónákban a szövetségesek kizárólagosan gyakorolták a legfelsóbb hatalmat.

A megállapodás értelmében szeptember 11-én a Szövetséges Tanács átvette Ausztria felett a legfóbb hatalmat. A szövetséges hatalmak az 1945. október 20-án kiadott és az ideiglenes kormány fejének, Karl Renner államkancellárnak (Staatskanzler) címzett Memorandummal szintén elismerték a kormányt, hangsúlyozva, hogy az ideiglenes kormány kizárólag a Szövetséges Tanács szupremáciájának alárendelve gyakorolhatja az államhatalmat Ausztria felett (Adamovich, 1947:42).

A memorandum révén létrejött az osztrák központi hatalom, az ideiglenes kormány és a szövetséges hatalmak közötti kapcsolat. A Memorandum kötelezte az ideiglenes kormányt, hogy 1945. december 31-ig írják ki a választásokat, továbbá felhatalmazta, hogy a teljes államterületre vonatkozóan elfogadhat törvényeket, kihirdetésükhöz azonban mindenkor szükséges a Szövetséges Tanács jóváhagyása. Mindezek ellenére a Szövetséges Tanács fenntartotta magának a jogot a katonai kormányzati törvényhozásra (Brauneder, 2003:264).

\section{A Zónaegyezmény}

1945. július 9-én a szövetségesek az Európai Tanácsadó Bizottság (European Advisory Commission) londoni konferenciáján megállapodtak Ausztria felosztásáról; területét 
négy részre osztották. A Szovjetunió Alsó-Ausztriát, Burgenlandot és Mühlviertelt, az Egyesült Államok Felsô-Ausztriát (Mühlviertel nélkül) és Salzburgot, Nagy-Britannia Stájerországot, Karintiát és Kelet-Tirolt, Franciaország Észak-Tirolt és Vorarlberget kapta.

A fôvárost, Bécset öt részre osztották. Az elsố kerületet leválasztották, és a megszálló hatalmak közös, nemzetközi igazgatása alá vonták. Az elsố kerületben volt az osztrák kormányzati központ, így lehetôvé vált, hogy a szövetséges hatalmak együttesen gyakorolják a felügyeletet az állami szervek felett. A kerület közigazgatását a szövetséges hatalmak havonta felváltva látták el.

A londoni Zónaegyezmény értelmében Ausztria, Olaszországgal ellentétben, közös megszállás alá került, de Németországtól eltérôen - melyet az 1937-es határain belül szálltak meg - rendelkezett saját központi hatalommal és egy egységes alkotmánnyal (Brauneder, 2003:264).

Ausztria területi felosztását a szövetségesek egymás között döntötték el, Ausztriának vesztes államként nem volt beleszólása a kérdésbe. A megszállás költségeit kezdetben teljes mértékben, késóbb csak részben hárították át Ausztriára. A 6,5 millió lakost számláló ország megszállására 700000 fôs szövetséges haderôt tartottak fenn. 1955-re a szovjetek már csak 40 000, a három nyugati szövetséges pedig összesen 20000 fôt állomásoztatott Ausztriában. A megszállás költségeit az Egyesült Államok 1947-tôl, míg a többi szövetséges hatalom 1953-tól már csak 35\%-ban hárította át az osztrák állami költségvetésre, 1955-ben pedig 15\%-ra csökkentették ezt az arányt (Szabó, 2008:177).

\section{A Második Ellenôrzési Megállapodás}

Az 1946. június 28-án aláírt Második Ellenőrzési Megállapodás már jóval enyhébb rendelkezéseket tartalmazott, és figyelembe vette az idóközben hatályba lépett 1920/29-es alkotmányt, ugyanakkor Ausztria továbbra sem volt szerzôdő fél. A Szövetséges Bizottság szerkezete megmaradt, ugyanakkor a katonai föparancsnokok feladatköreit a négy főbiztos (Hochkommissar) vette át. Az ellenôrzési jogkör az alábbi területekre terjedt ki:

- írásos jóváhagyás egy alkotmánytörvény elfogadása esetén;

- hallgatólagos jóváhagyás - amennyiben 31 napon belül egyik megszálló hatalom sem élt a vétójogával - az egyszerú törvények és nemzetközi szerzôdések esetében, utóbbiaknál csak akkor, ha nem az egyik megszálló hatalommal köttettek;

- vétójog valamennyi törvénytervezet vagy közigazgatási intézkedés eltörlésére vagy módosítására.

A Szövetséges Tanács jelentôsen korlátozta Ausztria szuverenitását. A szuverenitás korlátozása osztrák részről de jure nem került elfogadásra, de facto azonban igen (Brauneder, 2003:265). A Szövetségi Alkotmánytörvény elfogadása gyakorlati értelemben is a szuverenitás korlátozásának figyelmen kívül hagyását jelentette, hiszen a Szövetséges Tanács utasítására el kellett volna fogadni egy új, demokratikus elveken nyugvó alkotmányt, ehelyett a régi alkotmány visszaállítása történt.

A megállapodás elsôsorban a törvényhozási eljárásokat érintette, azok közül is az alkotmányozó jogkört. A szövetségesek egy különleges alkotmányozási gyakorlathoz folyamodtak a két nagypártra, az ÖVP-re és az SPÖ-re támaszkodva. Az Ideiglenes 
Alkotmány hatályon kívül helyezése ellenére továbbra sem a parlament került az alkotmányozás középpontjába, hanem a szövetségi kormány. A politikai döntések vagy itt, vagy egy, az alkotmány keretein kívül múködô és a két párt delegáltjaiból álló koalíciós bizottságban születtek. Az alkotmányos kérdések már a kormányjavaslat megszületésekor eldôltek, a parlament szerepe csak a formalitásra korlátozódott. A koalíciós paktum, az alkotmányozó jogkör tekintetében, a gyakorlatban megszüntette a törvényhozó és a végrehajtó hatalom elválasztását az utóbbi javára, mely megakadályozta a parlamenti kontroll érvényesülését (Brauneder, 2003:265).

\section{AZ IDEIGLENES KORMÁNY MEGALAKULÁSA}

Az „osztrák területek felett egységesen múködô” kormány felállítására dr. Karl Renner kezdeményezése adott lehetôséget. Az ideiglenes kormány 1945. április 27-én alakult meg a három antifasiszta párt, az Osztrák Szocialista Párt (SPÖ), ${ }^{5}$ az Osztrák Néppárt (ÖVP) és az Osztrák Kommunista Párt (KPÖ) képviselóibôl, a szovjet katonai parancsnokság jóváhagyásával (Adamovich, 1947:36). Az ideiglenes kormányt egyedül a szovjet katonai parancsnokság ismerte el, így hatásköre csak a szovjet megszállási övezetre terjedt ki. A három nyugati szövetséges hatalom csak a szovjetek által felállított bábkormányként tekintett rá, és nem ismerte el létjogosultságát, így az általuk megszállt területeken nem rendelkezett hatáskörrel (Zöllner, 1990:531).

Az ideiglenes kormány megalakulásának napján három jelentôs közjogi nyilatkozatot adott ki (Adamovich, 1947:36), melyek kivétel nélkül az 1943-as, Ausztria függetlenségéról szóló Moszkvai Nyilatkozatot vették jogalapul:

- a Függetlenségi Nyilatkozat (Unabhängigkeitserklärung) az 1938-as Anschlusst semmisnek tekintette, és a Moszkvai Nyilatkozat alapján az 1920-as alkotmány szellemiségében visszaállította az Osztrák Köztársaságot (1. cikk). Alkotmányjogi értelemben többször hivatkoztak rá egy alkotmányozási aktus eredményeként, ezért szokás „elsố történeti alkotmányként” (historisch erste Verfassung) is hivatkozni rá (Adamovich-Funk, 1985:81). Szintén a Függetlenségi Nyilatkozatban hirdették ki az ideiglenes kormány felállítását;

- az államkancellár (Staatskanzler) nyilatkozatot adott ki, melyben tudatta, hogy az új kormány megkezdte munkáját;

- az államtitkárok kormánynyilatkozatot adtak ki a kormányzat politikai irányvonalairól.

Az 1945. július 17. és augusztus 2. között megtartott potsdami konferencián ugyan a nyugati megszálló hatalmak is elfogadták az ideiglenes kormány által kihirdetett Függetlenségi Nyilatkozatot, azonban magát a kormányt továbbra sem ismerték el. (Ez részben ellentmondásként is értelmezhetô, hiszen amennyiben egy kormány által kibocsátott jogi aktus jóváhagyásra kerül, úgy végeredményben magát a kormány létjogosultságát is elismerik). A három nagyhatalom megállapodott, hogy az ideiglenes kormány hatáskörének egész Ausztriára történő kiterjesztése kérdését az amerikai és a brit csapatok Bécsbe történố bevonulása után megvizsgálják. A nyugati szövetségesek a megszállási övezeteik felett múködô ellenkormány felállítását továbbra sem tartották 
kívánatosnak, mely az osztrák egység megtartása szempontjából rendkívül nagy jelentôséggel bírt, hiszen így nem fenyegetett az ország két részre szakadásának veszélye (Szabó, 2008:179).

A nyugati ellenkormány felállításának elvetéséhez nagyban hozzájárult, hogy a szocialista párt már 1945-ben elutasította a kommunista párttal történô egyesülést, így a szovjetek nem támaszkodhattak a marxista tábor teljes egészére. Az ideiglenes kormány pozícióját tovább erôsítette a nyugati szövetséges hatalmak körében, hogy a kormány mereven elhatárolódott a szovjet eszméktól. Ausztria helyzetét megkönynyítette az a tény, hogy a nyugati országrészt a nyugati szövetségesek szabadították fel, így az ideiglenes kormánynak nagyobb politikai mozgástere volt, és elkerülhette a szovjetekkel való kizárólagos kényszer-együttmúködést. Az egyedül a szovjetek által felszabadított és ismételten megszállt kelet-közép-európai országokkal ellentétben, a szovjetek nem tudták érvényesíteni az ún. szalámitaktikát az osztrák politikai élet kommunista hegemónia alá vonásában.

\section{A TARTOMÁNYOK STÁtusZA}

A háborút követốen a tartományok igazgatásának újjászervezése a központi kormányzattól függetlenül ment végbe. 1945 májusában létrejöttek az ideiglenes tartományi kormányok, amelyek részben a birodalmi helytartóktól (Reichsstatthalter) vették át a feladatköröket és a tartományi államhatalmat (Brauneder, 2003:259). A tartományok és a szövetség közötti különbségek áthidalásában a politikai pártok fontos szerepet játszottak. Az ÖVP 1945. július 29-én és augusztus 19-én Salzburgban, az SPÖ szeptember 13-14-én szintén Salzburgban tartotta ülését. Renner, akárcsak az elsô világháborút követố idôszakban, ismét a tartományi konferenciák segítségével kívánt párbeszédet teremteni a tartományok és a szövetség között.

Az államkormány szeptember 24. és 26. között összehívta az elsố tartományi konferenciát Alsó-Ausztria bécsi tartományi parlamentjében. A konferencián kezdetben kaotikus állapotok uralkodtak: mivel az ideiglenes kormányt a nyugati tartományok ekkor még nem ismerték el, nem volt világos, hogy a konferencián hivatalosan részt vesz-e a kormány. A britek hevesen tiltakoztak a konferencia kezdete elótt, és követelték, hogy a kormány lépjen vissza.

Az alkotmány kérdése viszonylag késôn került napirendre. A konferencia végül eredményesen zárult. A kommunista pártnak sikerült megtartania Franz Honnert a kormányban belügyekért felelős államtitkárként, akit a szocialisták is elfogadtak. Az ideiglenes kormányt minden tartomány elismerte, Renner pedig biztosította magának az államkancellári hivatalt, egészen az elsô választásokig. Az ÖVP számára is sikeresen zárult a konferencia: több új miniszter is a párt soraiból került ki, ${ }^{6}$ emellett számos követelésüket érvényesíteni tudták, melyek közül a legfontosabb az alkotmányt érintô volt. A konferencián megállapodás született a szövetségi államformáról, és döntöttek az ehhez szükséges Ideiglenes Alkotmány módosításáról.

Az Ideiglenes Alkotmány módosítását az 1945. október 9-10-i salzburgi második tartományi konferencia jogi bizottsága dolgozta ki. Több módosítás a terminológiát 
érintette, így például a tartományi bizottságot (Landesausschuss) a tartományi kormány (Landesregierung) megnevezés váltotta fel. A módosítások a szövetségi állami struktúrát is megváltoztatták. Az Ideiglenes Alkotmány módosítása a tartományi kormányok hatáskörébe utalta az 1920/29-es alkotmány 15. cikkének (1) bekezdésében foglalt törvényhozási jogköröket, melyek tartományi kompetenciáknak minôsültek. A tartományi törvényhozás megteremtésével a szövetségi kormány tartományi törvényekkel szembeni vétójogát is visszaállították. A hatáskörmegosztás restaurálásával és annak garantálására az alkotmánybíróság (Verfassungsgerichtshof) helyreállítására igény formálódott.

Ezeknek az egyezségeknek a jogerôre emelésére az ideiglenes államkormány 1945. október 12-én elfogadott egy alkotmánytörvényt (alkotmánynovellát), melyet a szövetségesek jóváhagyása után 1945. október 20-án hirdettek ki az Állami Közlönyben, ugyanazon a napon, amikor a nyugati szövetséges hatalmak elismerték az ideiglenes kormányt. Az októberi alkotmánynovella 1. cikk 18 (2) bekezdése egy klauzulát tartalmazott, miszerint az ideiglenes államkormány szükség esetén a tartományi hatáskörbe tartozó ügyekben is élhet törvényhozó hatalmával. Ezt a rendelkezést a salzburgi tartományi konferencián nem vitatták meg. A javaslat Renner kezdeményezésére született, aki ígéretet tett arra, hogy ezeket az eseteket megelózóen az ideiglenes kormány kapcsolatba lép a tartományokkal.

Az alkotmánynovella elfogadása mellett, ugyanezen a napon a kormány elfogadta az alkotmánybíróság és a közigazgatási bíróság (Verwaltungsgerichtshof) felállításáról szóló törvényt, melyre november 1-jén került sor (Wiederin, 2015:197-200). Ezt követôen az 1920/29-es alkotmány hatálybalépésével az osztrák olvasat szerint az egykori tartományi alkotmányok is hatályba léptek az 1933. március 5-i jogrendnek megfelelóen (Brauneder, 2003:259).

\section{A SZÖVETSÉGI ÉS A TARTOMÁNYI HATÁROK KÉRDÉSE}

\section{A Szövetség határai}

1946-ban Jugoszlávia területi követelésekkel lépett fel Ausztriával szemben Karintia (Klagenfurtot és Villachot is beleértve) és Stájerország egyes részeire, ezen túlmenôen különleges jogállást vagy áttelepítést követelt Jugoszláviába a burgenlandi horvátoknak és szlovéneknek. A jugoszláv kormány területi igényeit kezdetben kizárólag a Szovjetunió támogatta, de a jugoszláv-szovjet viszony megromlásával a szovjetek kihátráltak. A horvát és a szlovén kisebbségi jogok biztosítását azonban továbbra is támogatták, melyet késôbb belefoglaltak az Államszerzôdés 7. cikkébe. Csehszlovákia szintén területi követeléseket fogalmazott meg, ezeket azonban, nemzetközi támogatottság hiányában, Ausztria egyedül is képes volt elhárítani.

Dél-Tirol kérdése a háború utáni határrendezésnél került eló ismét. Az osztrák kormány diplomáciai úton próbálta visszaszerezni a tartományt, illetve annak legalább az északi részét Olaszországtól, vesztes államként azonban nem járt sikerrel a kezdeményezés. Karl Gruber osztrák és Alcide De Gasperi olasz külügyminiszter 1946. szeptember 
5-én írta alá a Párizsi Megállapodást, mely garantálta az osztrák lakosságnak a személyi kisebbségvédelmet és a területi autonómiát (Brauneder, 2003:262-263). A megállapodás értelmében az osztrák kisebbség számára biztosították az anyanyelvi oktatást, a német nyelv hivatalokban történô használatát, a közszolgálatban való egyenjogúságot, és felülvizsgálták a Hitler-Mussolini-megállapodás alapján az optáláshoz való jogot (állampolgárság választása), továbbá jogot kapott a regionális törvényhozó és végrehajtó hatalom gyakorlására. 1947. június 27-én létrejött a Trentino-Tiroler Etschland régió, mely jelentős olasz többséggel rendelkezett. A régión belül Dél-Tirol (Bozen tartomány) jogot kapott egy tartományi parlament (Landtag) és egy tartományi kormány (Landesregierung) felállítására, azonban meglehetôsen korlátozott törvényalkotó jogkörökkel, melyeket az olasz kormány késóbb tovább szúkített (Zöllner, 1990:534).

\section{A tartományi határok}

A Gauk területi felosztásától eltérôen, a tartományok visszaállítása az egykori határaiknak megfelelően történt. Burgenland 1945. október 1-jén nyerte vissza területét, ${ }^{7}$ Alsó-Ausztria 1954-ben kapta vissza a Bécsbe tagozódott községeket, Stájerország pedig 1948. július 1-jén, Felsô-Ausztria többszöri tiltakozása ellenére, megkapta Ausseerlandot.

Felsô-Ausztria részben az amerikai, részben a szovjet megszállási zónához (Mühlviertel) tartozott. Mühlviertel 1945-ben egy állami megbízott (Staatsbeauftragte) irányítása alá került, aki Felsô-Ausztria tartományfőnökének (Landeshauptmann) nevében gyakorolta annak hatásköreit. A gyakorlatban tehát létrejött egy tartományi kormány, anélkül azonban, hogy a Felsô-Ausztriával való alkotmányos egység megszúnt volna (Brauneder, 2003:263).

\section{Az ÁTMENET IDÓSZAKA}

A háború utáni állapotok nem tették lehetôvé az 1920-as alkotmány azonnali visszaállítását, ugyanis az abban foglalt alkotmányos intézményeket helyre kellett állítani. Nem létezett a Nemzeti Tanács (Nationalrat), és a tartományi gyúléseket (Landtag) is újjá kellett szervezni, melyek hiányában a szövetségi és a tartományi törvényhozó jogkört az ideiglenes kormányok gyakorolták. Mivel parlamenti testületek sem léteztek ebben az időszakban, az alkotmányozó hatalmat is az ideiglenes kormány gyakorolta, mely rendeletekkel ${ }^{8}$ kormányzott, azonban teljesen más politikai célokkal, mint tette azt a hivatásrendi állam (Ständestaat) ${ }^{9}$ idôszakában.

1945. május 1-jén az ideiglenes államkormány elfogadta az Alkotmány átmeneti törvényt (Verfassungs-Überleitungsgesetz), amely az alkotmányos rendet visszaállította az 1933. március 5-i állapotoknak megfelelóen. ${ }^{10}$ Ez azonban csak lépésról lépésre mehetett végbe. Az Alkotmány átmeneti törvénnyel egy napon az ideiglenes államkormány elfogadta az Ideiglenes Alkotmányt, mely provizórikusan az 1920/29-es alkotmány helyébe lépett, azzal a feltétellel, hogy hat hónappal az elsố szabadon választott népképviselet (Nemzeti Tanács) megalakulása után hatályát veszti [Alkotmány átme- 
neti törvény 4. cikk (2) bekezdés]. Az Ideiglenes Alkotmány 4. cikkének (2) bekezdése felhatalmazta az ideiglenes kormányt, hogy a szabadon választott népképviselet megalakulásáig teljeskörúen gyakorolja az állami törvényhozó és a legfelsôbb állami végrehajtó hatalmat. ${ }^{11}$ Bizonyos, a legfelsóbb végrehajtó hatalomhoz tartozó feladatok, melyek a Szövetségi Alkotmánytörvény értelmében a szövetségi elnököt illették, a Politikai Kabinettanácshoz (Politischer Kabinettsrat) kerültek. A Politikai Kabinettanácsot a három párt vezetőségéből megválasztott államtitkárok alkották, az államkancellár elnökletével (Adamovich, 1947:38).

Az alkotmányjog mellett az egyéb jogterületek visszaállítása is megtörtént. Az Alkotmány átmeneti törvény elfogadásával azonos napon elfogadták a Jog átmeneti törvény (Rechts-Überleitungsgesetz), mely a német birodalmi jogot hatályon kívül helyezte. Az 1945. július 28-án az Állami Közlönyben kihirdetett Hatósági átmeneti törvény pedig megszüntette a német birodalmi hatóságokat és rendelkezéseket, és az osztrák hatósági szervezetrendszert az 1938. március 13-i állapotoknak megfelelóen visszaállította (Brauneder, 2003:259).

Az Ideiglenes Alkotmány egy központilag irányított unitárius állammá formálta Ausztriát. A legfelsôbb állami szerv az ideiglenes államkormány volt, mely törvényeket, alkotmánytörvényeket alkothatott, és birtokolta a legfelsóbb végrehajtó államhatalmat. A tartományok igazgatása élén a tartományfönökök (Landeshauptmann) álltak, akik az ideiglenes államkormány illetékes tagjai alá voltak rendelve, és a kormánytól kapták kinevezésüket. A tartományok autonóm igazgatását az ideiglenes tartományi bizottságok látták el, melynek tagjai a tartományfónök, annak helyettesei és azok a személyek voltak, akiket a tartományfönök az ideiglenes államkormány egyetértésével nevezett ki (Adamovich-Funk, 1985:81). Ezek az alapelvek érvényesültek Bécs polgármesterének, polgármester-helyetteseinek és az ideiglenes városi szenátus (Provisorischer Stadtsenat) tagjainak megválasztásakor is (Adamovich, 1947:39).

1945. október 12-én a tartományok nyomására elfogadott Ideiglenes Alkotmány Novellája az ideiglenes államkormány törvényhozó kompetenciáját azokra a jogalkotási, illetve elvi jogalkotási ügykörökre korlátozta, melyek az 1920/29-es alkotmány 10-12. cikke értelmében a Szövetséget illették. Az alkotmány 15. cikkének (1) bekezdése alapján egyéb jogalkotási ügyekben az ideiglenes tartományi kormányokra ruházta a törvényhozó hatáskört. A tartományi törvényhatározatok (Gesetzbeschluss) azonban csak akkor léphettek hatályba, ha az ideiglenes kormány nem élt ellenvetéssel 4 héten belül (Adamovich, 1947:40). Ezzel az októberi alkotmánynovella visszaállította a föderális struktúrát.

1945. november 25-én az október 19-én elfogadott választási alkotmánytörvény alapján megtartották a háború utáni elsô szabad Nemzeti Tanács, a tartománygyúlések és Bécs város Községi Tanácsának választását. A Nemzeti Tanács december 19-én ült össze; ezen a napon véget ért az alkotmányos átmenet idôszaka. Az uralkodó jogfelfogás abból indult ki, hogy az Ideiglenes Alkotmány kizárólag eddig az idôpontig volt hatályos, és helyette a Szövetségi Alkotmánytörvény lépett egészében hatályba. Ez a felfogás az Alkotmány átmeneti törvény 4. cikkének (2) bekezdésén alapult (jóllehet, a hat hónapos idôszak kérdésében ellentmondás mutatkozik), miszerint az Ideiglenes 
Alkotmány „legkésóbb” hat hónappal az újonnan választott Nemzeti Tanács megalakulása után hatályát veszti (Adamovich-Funk, 1985:82).

A december 19-i elsố ülésen újabb Alkotmány átmeneti törvényt fogadtak el, azonban a szövetségesek egyet nem értése meghiúsította az Állami Közlönyben történô kihirdetését. ${ }^{12}$ Az érvényes közjogi gyakorlat értelmében már ezen a napon hatályba lépett az 1920/29-es Szövetségi Alkotmánytörvény ${ }^{13}$, és nem csak hat hónappal késóbb.

Valamennyi alkotmánytörvény, egyéb szövetségi törvény, nemzetközi egyezmény, illetve közigazgatási intézkedés elfogadása, végrehajtása és módosítása a Szövetséges Tanács jóváhagyásához volt kötött. Az 1945. december 19. utáni kormányzati rendszert a két nagypárt (ÖVP, SPÖ) nagykoalíciója határozta meg. A megszállásból adódó helyzet, a kommunista hatalomátvételtôl való fenyegetettség, illetve a közelmúlt történései megteremtették a politikai együttmúködést azon politikai erók között, amelyek az Elsố Köztársaság fennállása során még ellenséges viszonyban álltak egymással (Adamovich-Funk, 1985:82-83).

December 20-án az ÖVP (85 mandátum), az SPÖ (76 mandátum) és a KPÖ (4 mandátum) hárompárti koalíciójának eredményeként megalakult a Leopold Figl (ÖVP) vezette új kormány. A helyettes szövetségi kancellár Adolf Schärf (SPÖ) lett. A kormányt az ÖVP-ból nyolc miniszter, az SPÖ-ból hat miniszter, két független szakminiszter (pénzügyi és igazságügyi) és a KPÖ-ból egyetlen miniszter alkotta. A Nemzeti Tanácsba tehát csak kormánypárti képviselók kerültek, ellenzék nem alakult. Az ÖVP és az SPÖ közötti megállapodás alapján a kormányban, a tartományi és a községi közigazgatásban, a közszolgálatban és az államosított vállalatoknál egyaránt az arányossági elv valósult meg, melyet késôbb több alkalommal is módosítottak a választási eredményeknek megfelelốen.

Ugyanezen a napon a Szövetségi Gyúlés (Bundesversammlung) egyhangúan megválasztotta Karl Rennert a Második Osztrák Köztársaság elsô szövetségi elnökének (Bundespräsident), aki egészen az 1950. december 31-én bekövetkezett haláláig gyakorolta hivatalát (Zöllner, 1990:531-532).

\section{RENNER ÉS AZ UNitÁRIUS ÁlLAM GONDOLATA}

A szövetségi állam koncepciójáról szóló viták már 1945 áprilisában megkezdôdtek, amikor a 3. ukrán front parancsnoka, Fedor Tolbuhin a 2. kiáltványában biztosította az osztrák népet, hogy a Vörös Hadsereg tartja magát az 1943 októberében elfogadott, Ausztria függetlenségérôl szóló Moszkvai Nyilatkozathoz, és támogatja, hogy Ausztriában az 1938-ig érvényes állapotok visszaállításra kerüljenek. A kiáltvány azonban aggodalommal töltötte el az osztrák politikai vezetőket, akik az 1934-es autoriter alkotmány felélesztésének lehetôségét látták benne, mely az 1938. márciusi Anschlusshoz vezetett. A népi demokrácia felállítása egyedül a kommunistáknak állt érdekében, az 1945. áprilisban újjáalakuló szociáldemokrata és az újonnan létrejövô kereszténydemokrata politikai pártok elutasították (Wiederin, 2015:186).

Karl Renner tevékenysége további aggodalomra adott okot. 1945. április 1-jén felvette a kapcsolatot a szovjetekkel, és felajánlkozott a Második Köztársaság újjáépítô- 
jének szerepére. Renner a határozott fellépése, valamint politikai tapasztalata és az Elsố Köztársaság megalapításában betöltött kulcsszerepe okán elnyerte a szovjetek bizalmát. ${ }^{14}$ Ragaszkodott a 1920-as alkotmány és az 1918-1920-as köztársasági és közjogi tradíciók visszaállításához.

A Függetlenségi Nyilatkozat 1945. április 27-i kiadása szintén politikai vitákat eredményezett. Renner a Második Köztársaságot az 1920-as alkotmány szellemében kívánta felállítani, azonban ügyelt arra, hogy az „1920-as Szövetségi Alkotmánytörvény” (Bundes-Verfassungsgesetz 1920) vagy az „1920-as Szövetségi Alkotmány” (Bundesverfassung von 1920) kifejezések ne jelenjenek meg a Nyilatkozatban. Ez nem volt véletlen, hiszen Renner szövetségi állam helyett egységállamot (unitárius államot) kívánt felállítani (Wiederin, 2015:187).

Renner nem kívánt autonómiát adni a tartományoknak a Második Köztársaságban, mondván, hogy 1920 után azt a szövetségi kormány akadályoztatására használták fel, továbbá hozzájárultak a fasizmus megerősödéséhez és terjedéséhez, illetve nem léptek fel az ismételt alkotmánysértések ellen, mely a kötelességük lett volna. Az 1945. május 10-i kabinetülésen megjegyezte, hogy a szövetségi állam helyreállításától egyelôre nem zárkózik el, azonban úgy látja, hogy a tartományi parlamentek és a tartományfônökök reaktiválása az államhatalmat és a közellátást gátolhatják vagy fel is számolhatják, valamint nem tartotta indokoltnak egy Ausztria méretú állam esetében a szövetségi modell felállítását (ellenpéldaként az Amerikai Egyesült Államokat hozta fel).

Adolf Schärf államtitkár racionálisan érvelt Rennerrel szemben, és az 1920-as állapotok visszaállítása vagy az egységállami berendezkedés helyett az 1933. márciusi szövetségi állami berendezkedést javasolta. Kompromisszumként felajánlotta, hogy legyen merev, centralizáló alkotmány egy meghatározott átmeneti idôszak erejéig, ezt követốn viszont az 1933-ig fennálló alkotmányos berendezkedést kell ismét megteremteni, és minden további alkotmánymódosítást az 1933-ban hatályban lévô alkotmány keretei között kell elfogadni. Javaslataival Schärfnek végül sikerült meggyốznie Rennert a szövetségi állami berendezkedésról (Wiederin, 2015:188-189).

\section{A 2. és a 3. Alkotmány átmeneti törvény}

(DAS 2. UND DAS 3. VERFASSUNGS-ÜBERLEITUNGSGESETZ) $)^{15}$

Mint arról már korábban szó esett, az Alkotmány átmeneti törvény 4. cikk (2) bekezdése kimondta, hogy hat hónappal az után, hogy az általános, egyenlő, közvetlen és titkos választásokon megválasztott népképviselet (Nemzeti Tanács) elsô alkalommal összeül, az Ideiglenes Alkotmány hatályát veszti. A hat hónap azonban túl hosszú idônek bizonyult, ezért az államkormány el akarta fogadni a 2. Alkotmány átmeneti törvényt, lehetôvé téve a régi Szövetségi Alkotmány újbóli hatálybalépését. Ludwig Adamovich ${ }^{16}$ a 1929-es Alkotmány átmeneti törvényt alapul véve négy pontban foglalta össze a javaslatát (Wiederin, 2015:201):

- Az 1. cikk értelmében az újonnan megválasztott Nemzeti Tanács elsố ülésének napján a Szövetségi Alkotmány az 1929-es novellával, a tartományi alkotmányok az egyes tartományokban, Bécs alkotmánya az 1931-es módosított szerkezetben, ${ }^{17}$ vala- 
mint a Nemzeti Tanács (Nationalrat), a Szövetségi Tanács (Bundesrat), a tartományi parlamentek (Landtag) és a Bécsi Községi Tanács (Wiener Gemeinderat) ügyrendi szabályzata az 1933. március 5-i törvényhozás állapotának megfelelóen hatályba lépnek. Ugyanezen a napon az Alkotmány átmeneti törvény és az Ideiglenes Alkotmány hatályukat vesztik.

- A 2. cikk az 1920-as Alkotmány átmeneti törvény (Verfassungs-Übergangsgesetz) 2-6. cikkét tekintette alkalmazandónak, melyek átemelik a hatályos törvényeket és rendeleteket, és rendezik a feloszlott és újonnan létrejövố szervek közötti hatáskörátruházást.

- A 3. cikk azokat a szabályozásokat érinti, amelyek az újonnan hatályba lépô Szövetségi Alkotmánytörvény rendelkezéseitől eltérnek, és részben az átmenetre (szövetségi elnökválasztás, kormányzat, minisztériumok, számvevôszék, közjogi bíróságok), részben pedig az időbeliségre (állampolgárság, törvényesség elve, Szövetségi Tanács, büntetőeljárások, tartományi kormányok hivatalai) vonatkoznak.

- A 4. cikk a hatálybalépést szabályozta, és tartalmazott egy végrehajtási klauzulát.

A kormányülés, hosszas tanácskozás után, 1945. november 29-én elfogadta a javaslatot. A britek azonban 1945. december 10-én megtagadták a Szövetségi Tanácsban a jóváhagyást, ugyanis álláspontjuk szerint a végleges döntést Ausztria alkotmányos rendjének megfelelôen csak egy szabadon választott parlament hozhatja meg.

Adamovich a brit jogi bizottság vezetőjével, Claud Schusterrel kompromisszumot kötött, melynek értelmében a törvényhozó hatalom a Nemzeti Tanácsra, a Szövetségi Tanácsra és a tartományi parlamentekre szállt, az alkotmány kérdését azonban nyitva hagyta. A módosítási javaslatokat végrehajtva a kabinettanács (Kabinettsrat) 1945. december 13-án elfogadta a 2. Alkotmány átmeneti törvényt, melyet a szövetségesek jóváhagyását követôen, december 18-án kihirdettek, így december 19-én összeülhetett és megkezdhette munkáját a Nemzeti Tanács.

A még rendezetlen közjogi kérdéseket a 3. Alkotmány átmeneti törvényrôl készített javaslat volt hivatott szabályozni, melyet a kormány december 19-én a Nemzeti Tanács elé terjesztett. A magyarázó kommentárokban (Erläuternde Bemerkungen) az ideiglenes kormány rögzítette: feladata abban áll, hogy az alkotmányjog területén a legfontosabb rendelkezéseket kidolgozza, amelyek a törvényhozó testületek üléseit lehetôvé teszik, azonban nem illetékes az alkotmány egészének végrehajtásában. A javaslat értelmében az 1920/29-es alkotmányt érintô átmeneti rendelkezéseket a szabadon választott törvényhozó testületek jogosultak elfogadni.

Az alkotmányjogi hézagot kiküszöbölendô, a 3. Alkotmány átmeneti törvényrôl készült javaslat 4. cikk (1) bekezdése értelmében a törvény visszamenóleg ugyanazon a napon lép hatályba, amikor a Nemzeti Tanács elsô alkalommal összeült.

A Szövetséges Tanács azonban ismét megtagadta a törvénytervezet jóváhagyását. A Tanács 1946. március 31-i jegyzékében tudatta a szövetségi kancellárral, hogy március 25-i ülésén elfogadott egy határozatot, melyben kötelezi az osztrák kormányt, hogy legkésôbb július 1-jéig dolgozzon ki egy demokratikus elveken alapuló alkotmánytervezetet, és hogy nem hagyja jóvá az 1945. december 19-én kidolgozott törvénytervezetet. Ezúttal a szovjet fél élt vétójogával, ezzel akarta ugyanis erôsíteni a Kommunista Párt pozícióját az alkot- 
mányozás során. A Kommunista Párt a választásokon messze elmaradt a várakozásoktól, és éppen bejutott a Nemzeti Tanácsba. Politikai erejük növelése érdekében kinyilvánították, hogy az 1920/29-es Alkotmányt csak ideiglenesnek tekintik, és létkérdésnek tartják egy új, demokratikus alkotmány elfogadását (Wiederin, 2015:202-204).

A Szövetséges Tanács vétója és elvárásai ellenére, egy ügyes jogelméleti magyarázattal sikerült a „régi” alkotmányt visszaállítani, a hivatalos osztrák álláspont szerint ugyanis a Szövetségi Alkotmánytörvény már hatályos volt. Leopold Figl szövetségi kancellár 1946. április 12-i, Nemzeti Tanácsban tartott beszédében az Ideiglenes Alkotmány kiegészítő jellegére hívta fel a figyelmet. A Szövetségi Alkotmánytörvény párhuzamosan létezett mellette. A magyarázat szerint a Szövetséges Tanács az 1945. május 1-jei 1. Alkotmány átmeneti törvény jóváhagyásával egyidejúleg jóváhagyta a Szövetségi Alkotmánytörvényt is, valamint Ausztria megtartotta az elsố szabad választásokat. Ekképp az Alkotmány, tekintet nélkül a Nemzeti Tanács 1945. december 19-i határozatára, a hatályos jogrend szerves részét képezi. Az Alkotmány bizonyos rendelkezéseinek érvényesülését akadályozó tényezôk a Nemzeti Tanács és a tartományi parlamentek megalakulásával megszúntek, és ettôl az időponttól kezdve az alkotmány hatályba lépett.

Az idó múlása Ausztriának kedvezett, hiszen az 1945-ös 1. Alkotmány átmeneti törvény 4. cikk (2) bekezdésében foglaltak alapján a hatálybalépés idópontja, 1946. június 19. közeledett. Az osztrák álláspont melletti határozott fellépés a régi alkotmány restaurációjának malmára hajtotta a vizet. Végül június 19-én hivatalosan is hatályát vesztette az Ideiglenes Alkotmány, és helyébe a régi-új Szövetségi Alkotmánytörvény lépett. A politikai viták ezzel végérvényesen lezárultak, és a Szövetséges Tanács sem élt további követeléssel egy új alkotmány kidolgozására (Wiederin, 2015:204-205).

\section{A KONTINUITÁS KÉRDÉSE}

Az 1945-ben elfogadott alkotmányjogi aktusok felvetik az alkotmányjogi kontinuitás-diszkontinuitás dilemmáját. Anyagi jogilag a Függetlenségi Nyilatkozat és az Alkotmány átmeneti törvény az 1920-as alkotmányt és annak 1929-es novelláját, valamennyi szövetségi alkotmánytörvényt és egyszerú szövetségi törvényben elfogadott alkotmányos rendelkezést az 1933. március 5-i jogrendnek megfelelôen visszaállította, így megvalósul a jogkontinuitás. Formálisan nézve azonban ezek a jogi aktusok nem vezethetốk vissza a régi alkotmányos jogrendre, hiszen az 1933. március 5. utáni alkotmányos rendszer és az 1938. március 12-i Anschluss véget vetett a korábbi alkotmányos rendnek. A Függetlenségi Nyilatkozatra használatos „elsô történeti alkotmány” kifejezés ennek hatására született (Adamovich-Funk, 1985:15).

\section{Ös S ZEGZÉS}

A háború után az osztrák államiság helyreállítása volt a cél, nem pedig egy új állam alapítása, ahogy történt az az elsô világháború után. Az osztrák államiság kapcsán létezik az annexiós (Annexionstheorie) és az okkupációs (Okkupationstheorie) elmélet. Az 
uralkodó felfogás ez utóbbit vallotta, azaz Ausztriát nem kebelezte be a Német Birodalom, csak katonailag megszállta, így ugyan 1938-ban elvesztette cselekvôképességét, de maga az állam nem szúnt meg létezni. A cselekvôképtelenség az 1945-ös felszabadítással ért véget.

Az osztrák szövetségi kormány és a német birodalmi kormány egyaránt a bekebelezési elméletet vallotta 1938-ban, és ez a nézet uralkodott a nemzetközi felfogásban is egészen 1943-ig. 1945 után háttérbe szorult, és csak egy szúkebb réteg képviselte ezt az álláspontot, amely ellenezte az 1933-as jogrend visszaállítását.

Az annexiós elmélet szerint 1945-ben, akárcsak 1918-ban, egy új állam született, így az 1938 előtti államisággal és a Német Birodalommal szemben egyaránt diszkontinuitás áll fenn. Az okkupációs elmélet az alkotmány- és a nemzetközijog-ellenes körülményekre hivatkozva - melyek az Anschlusshoz vezettek - az 1918-ban létrejött Elsô Osztrák Köztársasággal való kontinuitást és a Német Birodalommal szembeni diszkontinuitást mondja ki.

Az 1945 utáni új, avagy régi-új osztrák állam elnevezésében is ez a két elmélet játszott szerepet. Ha az 1918 és 1938 közötti államiságot az Első Köztársaság elnevezéssel illetjük, akkor nyilvánvalóan az 1945 utáni államiságra a Második Köztársaság fogalom használatos, amely az annexiós elméletnek felel meg. Az okkupációs elmélet ezzel ellentétben az 1945 utáni államot az Elsô Köztársaság folytatásának tartja (Brauneder, 2003:262). A gyakorlatban azonban az 1945 utáni államépítési, állam-újjáépítési idôszakot mindkét teória áthatotta. Az államot a Második Köztársaság névvel szokás illetni, mely értelemszerúen a bekebelezési elméletnek felel meg, ugyanakkor a korabeli jogalkotásban az okkupációs elmélet volt az uralkodó, tekintve hogy az osztrák államiság „visszaállítása” az 1933. március 5-i jogrendnek megfelelóen történt, beleértve az 1920/29-es Alkotmánytörvényt, és az állam hivatalos neve ismét Osztrák Köztársaság (Republik Österreich) lett, akárcsak 1920-ban az alkotmány hatálybalépését követôen.

\section{JEGYZETEK}

1 A Moszkvai Értekezleten (1943. október 19-30.) az Amerikai Egyesült Államok, az Egyesült Királyság, a Szovjetunió és Kína kormánya (ez utóbbi állam moszkvai nagykövete) közös nyilatkozatot adott ki, hogy a tengelyhatalmak feltétel nélküli kapitulációjáig folytatni fogják a háborút. Az Értekezleten négy nyilatkozatot fogadtak el: 1. Négy nemzet nyilatkozata az általános biztonságról, 2. Nyilatkozat Olaszországról, 3. Nyilatkozat Ausztriáról, 4. Háromhatalmi nyilatkozat a kegyetlenkedésekról.

2 A Moszkvai Nyilatkozat Ausztria vonatkozásában némileg ellentmondásos, hiszen egy katonai erôszakkal annektált állam nem viselhet felelôsséget cselekvôképessége hiányában, így szét kell választani az állampolgárok és az állam felelôsségét. A háborús bưnöket elkövetô osztrák állampolgárokat valóban felelốsség terhelte (Szabó, 2008:176).

3 www.bibl.u-szeged.hu/bibl/mil/ww2/doksi/moszkva.html (Letöltés: 2017. február 6.).

4 A német „Abkommen” kifejezés egyaránt jelent egyezményt és megállapodást, így ezeket a kifejezéseket egymás szinonimáiként használom.

5 Az SPÖ-t szokás szociáldemokrata pártnak is nevezni. Az újjászervezett párt hivatalos neve azonban Sozialistische Partei Österreichs (Osztrák Szocialista Párt, SPÖ) lett, tagjai a szociáldemokraták és a forradalmár szocialisták voltak. 


\section{Maróti Dávid: A Második Osztrák Köztársaság az átmeneti idôszakban}

${ }^{6}$ Az új kormányba az ÖVP 13, az SPÖ 12, a KPÖ 10 tagot delegált. Mellettük 4 független szakértố kormánytag is helyet kapott a kormányban (Zöllner, 1990:531).

7 Burgenland az 1938. március 12-i Anschluss-szal megszúnt létezni, területét Reichsgau Niederdonau és Reichsgau Steiermark között osztották fel.

8 A rendeleti kormányzás németrốl történô fordítása nem pontos. A „Regierungsgesetzgebung” tükörfordítása kormánytörvényhozás, azonban a magyar terminológiában ismeretlen ez a fogalom.

9 A hivatásrendi állam az 1920/29-es alkotmányt felváltó Májusi Alkotmány keretein belül 1934. május 1. és 1938. március 13. között múködött, www.aeiou.at/aeiou.encyclop.s/s772608.htm (Letöltés: 2017. február 6.).

10 A Nemzeti Tanács (alsóház) 1933. március 4-i ülése heves politikai vitákba torkollott (a politikai mandátumok tekintetében nem volt jelentôs különbség a kormány és az ellenzék között), mely végül a Nemzeti Tanács teljes elnökségének lemondásához vezetett. Az ezt követố jogi helyzet egy joghézag miatt kritikussá vált, hiszen sem az alkotmány, sem pedig a Nemzeti Tanács ügyrendje nem tartalmazott elő́rásokat a teljes elnökség lemondása esetére. Elnök nélkül nem volt, aki az üléseket vezesse, így az alsóház döntésképtelenné vált, és új elnököt sem tudott választani. A Nemzeti Tanács múködésképtelenségét kihasználva a szövetségi kormány rendeleti kormányzásba kezdett (Szabó, 2010:301-304).

11 www.verfassungen.de/at/at45-/vgesetz45-2.htm (Letöltés: 2017. február 7.).

12 Lásd részletesen A 2. és a 3. Alkotmány átmeneti törvény (das 2. und das 3. Verfassungs-Überleitungsgesetz) c. fejezetben.

13 www.verfassungen.de/at/at45-/vgesetz45-1.htm (Letöltés: 2017. február 7.).

14 Az elsố világháborút követôen Karl Rennert választották a Német-Ausztriai Köztársaság (Republik Deutschösterreich, Republik Deutsch-Österreich) államkancellárjának (Staatskanzler) és az Elsô Osztrák Köztársaság (Republik Österreich) elsố kancellárjának (szintén államkancellári titulusban), akinek az 1920-as alkotmány kidolgozásában is jelentôs szerepe volt.

15 Az Alkotmány átmeneti törvényre a német nyelvben két kifejezés használatos: Verfassungs-Überleitungsgesetz, Verfassungs-Übergangsgesetz.

16 Renner államkancellár felkérésének eleget téve dr. Ludwig Adamovich jogszakértôként részt vett a kormányüléseken.

17 Bécs alkotmánya az 1931-es szerkezetben már 1945. július 14-én hatályba lépett (Staatsgesetzblatt Nr. 67/1945: Neuerliches Wirksamwerden der Verfassung der Stadt Wien in der Fassung von 1931, Wiener Verfassungs-Überleitungsgesetz, WV-ÜG), azonban 1945. december 19-ig több átmeneti rendelkezéssel is kiegészítették, majd ismét hatályba lépett. Adamovich tervezete Bécs alkotmányának újbóli hatálybaléptetésére vonatkozott. www.verfassungen.de/at/wien/verf45-i.htm (Letöltés: 2017. március 7.).

\section{FELHASZNÁLT IRODALOM}

Adamovich, Ludwig (1947): Grundriss des Österreichischen Verfassungsrechts. Vierte, neubearbeitete Auflage, Springer Verlag, Wien, 36-42.

Adamovich, Ludwig - Funk, Bernd-Christian (1985): Österreichisches Verfassungsrecht. Dritte, neubearbeitete Auflage, Springer Verlag, Wien, 81-83.

Brauneder, Wilhelm (2003): Österreichische Verfassungsgeschichte. 9. durchgesehene Auflage, Manz Verlag, Wien, 255-265.

Szabó István (2010): Ausztria államszervezete 1918-1955. PPKE JÁK, Budapest, 301-304.

Szabó István (2008): Ausztria négyhatalmi megszállása és az 1955-ös Államszerzôdés. Sectio Juridica et Politica, Tomus XXVI/1, Miskolc, 176-179.

Wiederin, Ewald (2015): Einheitsstaat oder Bundesstaat? Diskurse und Entscheidungen 1945. In: Rechtshistorische Aspekte des österreichischen Föderalismus, Beiträge zur Tagung an der Universität Innsbruck am 28. und 29. November 2013. Hrsg. Martin Schennach, Sammelband, Verlag Österreich, Wien, 186-205.

Zöllner, Erich (1990): Geschichte Österreichs von den Anfängen bis zur Gegenwart. 8. Auflage, Verlag für Geschichte und Politik Wien, Wien, 531-534. 